\title{
Pentingnya Pencegahan Dini dan Tata laksana Alergi Susu Sapi
}

\author{
Sjawitri P Siregar, Munasir Zakiudin
}

\begin{abstract}
Alergi susu sapi (ASS) merupakan penyakit atopik pertama pada seorang anak, karena mekanisme pertahananspesifik dan non-spesifik saluran cerna bayi belum sempurna. Diagnosis ASS harus ditegakkan sedini mungkin karena memberikan gejala klinis beraneka ragam seperti dermatitis atopik, urtikaria, muntah, kolik, diare, batuk kronik berulang, asma sampai anafilaksis. Pemeriksaan baku emas untuk ASS adalah double blind placebo controlled food challange (DBPCFC) selain anamnesis, tanda-tanda atopi pada pemeriksaan fisis, dan pemeriksaan imunoglobulin $\mathrm{E}$ total dan spesifik susu sapi. Penghindaran susu sapi harus dikerjakan sampai terjadi toleransi sekitar usia 2-3 tahun sehingga harus diberikan susu pengganti formula soya atau susu sapi hidrolisat sempurna dan makanan padat bebas susu sapi dan produk susu sapi. Pencegahan alergi harus dikerjakan sedini mungkin pada anak berisiko atopik, dikenal tiga jenis pencegahan yaitu pencegahan primer, sekunder dan tersier.
\end{abstract}

Kata kunci: DBPCFC, pencegahan alergi.

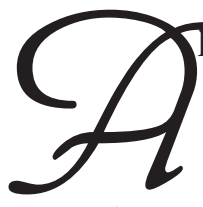

Pergi merupakan masalah penting yang harus diperhatikan karena terdapat pada semua lapisan masyarakat dan insidennya meningkat pada tiga periode terakhir. Pada usia tahun pertama kehidupan, sistim imun seorang anak relatif masih imatur dan sangat rentan. Bila ia mempunyai bakat atopik akan mudah tersensitisasi dan berkembang menjadi penyakit alergi terhadap alergen tertentu misalnya makanan dan inhalan.

Susu sapi adalah protein asing utama yang diberikan kepada seorang bayi, penyakit alergi susu sapi (ASS) sering merupakan penyakit atopik pertama pada seorang anak ${ }^{1}$ Harus dibedakan antara ASS suatu reaksi imunologis dan reaksi intoleransi yang bukan

Alamat korespondensi:

Dr. Sjawitri P. Siregar, Sp.A(K). Divisi Alergi Imunologi. Departemen Ilmu Kesehatan Anak FKUI RSCM, Jakarta. Jl. Salemba No. 6, Jakarta 10430. Telepon 021-316 1144. Fax. 021-3907743. berdasarkan kelainan imunologis seperti efek toksik dari bakteri stafilokok, defek metabolik akibat kekurangan enzim laktase dan reaksi idiosinkrasi.

Diperkirakan insiden ASS 2-3\% bayi, sedangkan diantara bayi umur 1 tahun dengan dermatitis atopik 30-45\% disebabkan ASS. 5,6,7 Di samping gejala pada kulit, ASS dapat menunjukkan gejala paru dan gejala saluran cerna tipe segera bahkan gejala sistemik berupa reaksi anafilaksis. ${ }^{1}$ Diperkirakan ASS dapat juga memberikan gejala reaksi tipe lambat yang timbul setelah 24 jam berupa sindrom kolik pada usia bayi ( infantile colic syndrome).

Diagnosis penyakit ASS pada bayi dan anak yang dicurigai melibatkan pemeriksaan in vitro dan in vivo. ${ }^{8}$ Setelah anamnesis dan pemeriksaan fisis, maka dibuktikan adanya sensitisasi susu sapi dengan pemeriksaan IgE spesifik susu sapi dan atau uji kulit terhadap susu sapi. Bila hasil positif dilanjutkan dengan uji provokasi dengan cara double blind placebo control food 
challenge (DBPCFC), karena cara ini adalah baku emas untuk menegakkan diagnosis ASS secara objektif. 8,9

Tata laksana ASS mencakup juga penghindaran susu sapi dan makanan yang mengandung susu sapi, dengan memberikan susu kedele sampai terjadi toleransi terhadap susu sapi. Perbedaan yang mencolok antara penyakit ASS dan alergi terhadap makanan lain pada bayi adalah bahwa toleransi dapat terjadi secara spontan semasa usia dini. Penelitian menunjukkan bahwa $85 \%$ ASS akan ditoleransi sebelum anak berumur 3 tahun ${ }^{2,3,10}$. Walaupun akan terjadi toleransi pada usia tersebut, tindakan pencegahan maupun tata laksana yang tepat perlu untuk mencegah terjadinya alergi yang lebih parah serta alergi terhadap makanan alergen lain di kemudian hari.

\section{Definisi}

ASS adalah suatu penyakit yang berdasarkan reaksi imunologis yang timbul sebagai akibat pemberian susu sapi atau makanan yang mengandung susu sapi dan reaksi ini dapat terjadi segera atau lambat. ${ }^{11,12}$

\section{Alergen pada susu sapi}

Protein susu sapi merupakan alergen tersering pada berbagai reaksi hipersensitivitas pada anak. ${ }^{13}$ Susu sapi mengandung sedikitnya 20 komponen protein yang dapat merangsang produksi antibodi manusia. ${ }^{14}$ Protein susu sapi terdiri 2 fraksi yaitu casein dan whey. ${ }^{14}$ Fraksi casein yang membuat susu berbentuk kental (milky) dan merupakan $76 \%$ sampai $86 \%$ dari protein susu sapi. ${ }^{15}$ Fraksi casein dapat dipresipitasi dengan zat asam pada $\mathrm{pH}$ 4,6 yang menghasilkan 5 casein dasar yaitu $\alpha, \alpha \delta, \beta, \kappa$ dan $\gamma$.

Beberapa protein whey mengalami denaturasi dengan pemanasan ekstensif (albumin serum bovin, gamaglobulin bovin, dan $\alpha$-laktalbumin). Akan tetapi, dengan pasteurisasi rutin tidak cukup untuk denaturasi protein ini tetapi sebaliknya meningkatkan sifat alergenitas beberapa protein susu seperti $\beta$-laktoglobulin.

\section{Barier saluran cerna terhadap alergen makanan}

Fungsi utama saluran cerna ialah memproses makanan yang dikonsumsi menjadi bentuk yang dapat diserap dan digunakan untuk energi dan pertumbuhan sel. Selama proses ini berlangsung, mekanisme imunologik dan non-imunologik berperan dalam pencegahan masuknya antigen asing ke dalam tubuh. Pada bayi baru lahir kadar SIgA dalam usus masih rendah sehingga antigen mudah menembus mukosa usus dan kemudian dibawa ke aliran darah sistemik ${ }^{16,17}$ Tabel 1

Tabel 1. Barier terhadap antigen makanan

Non imunologik

- Menghalangi antigen makanan masuk ke mukosa dengan cara

Peristaltik usus

Lapisan mucus di usus

Komposisi membran mikrovili usus

- Memecah antigen yang masuk dengan cara

Asam lambung dan pepsin

Enzim pankreas

Enzim usus

Aktivitas lizosim sel epitel usus

Imunologik

- Menghalangi antigen masuk ke mukosa usus

S-IgA spesifik dalam lumen usus

- Membersihkan antigen yang telah menembus mukosa usus

IgA dan IgG spesifik dalam serum

Sistem retikuloendotelial

*Dikutip dengan modifikasi dari Sampson HA, $1991{ }^{18}$

\section{Gambaran klinis Alergi Susu Sapi}

Gejala ASS pada umumnya dimulai pada usia 6 bulan pertama kehidupan. Dua puluh delapan persen timbul setelah 3 hari minum susu sapi, $41 \%$ setelah 7 hari dan $68 \%$ setelah 1 bulan ${ }^{19}$.Berbagai manifestasi klinis dapat timbul. Pada bayi terdapat 3 sistem organ tubuh yang paling sering terkena yaitu kulit, sistem saluran napas, dan saluran cerna. ${ }^{16 .}$

- Gejala klinis yang dapat terjadi pada ketiga sistem tersebut adalah

- Kulit: urtikaria, kemerahan kulit, pruritus, dermatitis atopik

- Saluran napas: hidung tersumbat, rinitis, batuk berulang dan asma

- Saluran cerna: muntah, kolik, konstipasi, diare, buang air besar berdarah

- Gejala sistemik: syok 
Penyakit ASS akan menghilang (toleran) sebelum usia 3 tahun pada $85 \%$ kasus. ${ }^{2,3,10}$ Sebagian besar ASS pada bayi adalah tipe cepat yang diperan oleh IgE dan gejala utama adalah ras kulit, eritema perioral, angioedema, urtikaria dan anafilaksis, sedangkan bila gejala lambat dan mengenai saluran cerna berupa kolik, muntah dan diare biasanya bukan diperan oleh IgE. ${ }^{20}$

\section{Diagnosis}

Diagnosis ASS ditegakkan berdasarkan anamnesis, pemeriksaan fisis, dan pemeriksaan penunjang

\section{Anamnesis}

- Jangka waktu timbulnya gejala setelah minum susu sapi/ makanan yang mengandung susu sapi

- Jumlah susu yang diminum/makanan mengandung susu sapi

- Penyakit atopi seperti asma, rinitis alergi, dermatitis atopik, urtikaria, alergi makanan, dan alergi obat pada keluarga (orang tua, saudara, kakek, nenek dari orang tua), dan pasien sendiri.

- Gejala klinis pada kulit seperti urtikaria, dermatitis atopik, ras

- Saluran napas: batuk berulang terutama pada malam hari, setelah latihan asma, rinitis alergi

- Saluran cerna, muntah, diare, kolik dan obstipasi.

\section{Pemeriksaan fisis}

Pada kulit tampak kekeringan kulit, urtikaria, dermatitis atopik allergic shiner's, Siemen grease, geographic tongue, mukosa hidung pucat, dan mengi.

\section{Pemeriksaan penunjang}

1. Darah tepi, hitung jenis eosinofil $>3 \%$ atau eosinofil total $>300 / \mathrm{ml}$. Kadar IgE total, nilai normal disesuaikan dengan umur. Kadar IgE spesifik susu sapi. Bila kadar IgE total dan atau IgE spesifik susu sapi meninggi, berarti sudah terjadi sensitisasi dengan susu sapi. Pemeriksaan IgE spesifik dapat dilakukan dengan berbagai cara, misalnya cara IgE RAST (radio allergo sorbent test) dinyatakan positif bila nilainya $>$ atau sama dengan 1. Uji IgE RAST positif mempunyai korelasi yang baik dengan uji kulit. ${ }^{21}$ Dapat juga diperiksa dengan cara CAP sistim FEIA dinyatakan positif bila nilainya $>32 \mathrm{kUa} / \mathrm{l}$, cara ini akan mempunyai korelasi yang baik dengan gejala klinis dan uji eliminasi dan provokasi buta ganda (double blind placebo control food challenge). Untuk uji tapis bahwa seorang sudah tersensitisasi, tidak cukup hanya dengan kadar IgE saja, karena kadar IgE dapat juga tinggi pada orang normal dan kadar normal tidak menyingkirkan ASS, sehingga untuk menghindarkan negatif palsu maka harus dilanjutkan dengan uji kulit.

2. Uji kulit

Terdapat berbagai cara uji kulit; uji kulit gores, uji tusuk dan uji kulit intradermal.

Diantara uji tersebut, yang sering dilakukan adalah uji kulit tusuk, walaupun uji intradermal lebih sensitif. Beberapa hal harus diperhatikan untuk melakukan uji kulit (Tabel 2). Bila hasil uji kulit positif kemungkinan ASS 50\% karena prediksi positif akurasinya $<50 \%$, sedangkan bila hasil uji kulit negatip berarti ASS IgE mediated dapat disingkirkan karena prediksi negatip akurasinya $95 \% .{ }^{22,23}$ Uji kulit pada usia $<1$ tahun sering memberikan hasil negatip palsu, tetapi bila hasilnya positif maka dugaan sangat mungkin menjurus ASS. ${ }^{22}$ Penilaian besar indurasi berbeda antara anak usia $<2$ tahun dan anak $>2$ tahun. Bila indurasi $>$ $8 \mathrm{~mm}$ pada usia $>2$ tahun dan indurasi $>6 \mathrm{~mm}$ pada usia $<2$ tahun akan mempunyai korelasi yang baik dengan uji DBPCFC. ${ }^{24}$ Bila salah satu uji kulit atau kadar IgE total atau IgE spesifik positif dan disertai pada anamnesis dan pemeriksaan fisik dugaan ASS, maka dilanjutkan dengan uji eliminasi dan provokasi susu sapi.

3. Ada beberapa cara untuk provokasi makanan, sebagai baku emas adalah DBPCFC. Cara ini memerlukan waktu dan mahal, sehingga dicari cara yang lebih mudah. ${ }^{25}$ Persyaratan uji provokasi oral tertera pada Tabel 2

- Provokasi makanan terbuka, setelah eliminasi susu sapi selama 2-3 minggu dan gejala berkurang atau menghilang, maka susu sapi diberikan secara bertahap mulai $3 \mathrm{ml}$ dinaikkan menjadi $6 \mathrm{ml}, 12 \mathrm{ml}$ sampai tercapai jumlah susu yang diminum, interval pemberiannya tiap10 menit. Bila setelah 2 jam tidak timbul 
gejala, berarti uji provokasi negatip dan anak dinyatakan tidak ASS. Provokasi ini sering dilakukan pada anak di bawah 3 tahun. Untuk anak $>3$ tahun diberikan buku harian. Buku dinilai setelah 2 minggu, untuk menduga bahwa gejala yang timbul akibat mengkonsumsi susu sapi (Tabel 3). Lalu diberikan diet eliminasi selama 2 minggu, bila gejala membaik atau hilang, diberikan provokasi dengan susu sapi bertahap secara terbuka mulai dengan jumlah $10 \mathrm{ml}$ dinaikkan bertahap dengan interval 10 menit, sampai jumlah yang dikonsumsi. Provokasi terbuka dapat dikerjakan di rumah, kecuali bila gejala yang timbul anafilaksis atau angioedem, sebaiknya di rumah sakit.

- Rogier Schade membuat modifikasi doubleblind, placebo controlled cow's milk challenge, dapat dilakukan di ruang rawat sehari untuk bayi dan anak yang tersangka ASS ${ }^{26}$

Tabel 2. Persyaratan uji provokasi oral

- Penghindaran makanan yang mengandung susu sapi minimal 2 minggu

- Penghindaran obat antihistamin selama 3-7 hari

- Penghindaran obat bronkodilator, kromolin, nedokromil dan steroid inhalasi 6-12 jam sebelum provokasi

- Tersedia obat obat untuk mengatasi reaksi anafilaksis yang mungkin terjadi

- Pasien dipuasakan selama 2-3 jam sebelum provokasi

- Besar dosis permulaan harus kurang dari dosis yang diperkirakan akan menimbulkan reaksi, bila tidak diketahui dimulai dengan dosis $400 \mathrm{mg}$ susu bubuk

- Dosis kumulatif 8-10 gram bahan bubuk harus dicapai untuk menyatakan hasil negatif

- Pasien harus di awasi sampai 2 jam setelah provokasi selesai, bila reaksi IgE mediated, bila timbul lebih lama maka observasi harus disesuaikan

Dikutip dari Sampson HA, $1991^{18}$

Disediakan 2 formula, formula plasebo yang berisikan Nutramigen (Mead Johnson) suatu formula hidrolisat. Pada formula yang berisi susu sapi yang diminum $(1,8 \mathrm{gram} / 100 \mathrm{ml})$ dengan mencampur Nutramigen dan Protifar berbanding 11:3. Kedua jenis formula mempunyai aroma dan rasa yang sama kemudian dimasukkan dalam botol yang sama bentuk dan warnanya, diberi nama formula A dan formula B. Anak dirawat di ruang rawat sehari, setelah dilakukan pemeriksaan fisik, diberikan formula A setetes di bibir, diawasi gejala setelah 15 menit, bila negatip dilanjutkan dengan skema tabel 3. Bila setelah 1 jam diprovokasi dengan formula A tidak timbul gejala, maka dilanjutkan dengan formula $\mathrm{B}$ dengan cara dan skema sama seperti sebelumnya. Bila pada kedua formula tidak timbul gejala, maka pasien dipulangkan keesokan harinya dan sudah boleh minum susu sapi seperti biasa. Ketika provokasi berlangsung, pemeriksaan fisis dilakukan dan diawasi gejala yang timbul dan dicatat. Bila gejala yang timbul meragukan, maka diulang dengan dosis yang diberikan terakhir, sebelum melanjutkan ke dosis lebih tinggi. Bila timbul gejala, maka provokasi dihentikan segera dan diberikan obat. Kemudian formula tersebut dibuka, hasil provokasi positif bila formula yang mengandung susu sapi yang menimbulkan gejala. (Tabel 3)

4. Pemeriksaan kadar histamin yang dilepaskan sel mas dan sel basofil. Dengan cara setelah provokasi dengan susu sapi dilakukan diukur histamin dengan memasang intragastric tube. ${ }^{27}$ Untuk menyingkirkan cow's milk protein induced enterocolitis, ${ }^{2}$ dilakukan biopsi yeyunum.

5. Pemeriksaan hambatan migrasi leukosit untuk membuktikan imunitas selular terlibat pada ASS. ${ }^{2}$

\section{Tata laksana}

Bila diagnosis ASS sudah ditegakkan maka susu sapi harus dihindarkan dengan ketat supaya toleransi dapat

Tabel 3. Protokol provokasi double-blind, placebo controlled cow's milk challenge

\begin{tabular}{ccc}
\hline Langkah & Waktu (menit) & Jumlah $(\mathrm{ml})$ \\
\hline 1 & 0 & Setetes \\
2 & 15 & 10 \\
3 & 40 & 20 \\
4 & 60 & 30 \\
5 & 80 & 40 \\
6 & 110 & 60 \\
7 & 150 & 90 \\
\hline
\end{tabular}

Dikutip dari RP Schade, $2001^{26}$ 
cepat tercapai. Lima puluh persen akan toleran pada usia 2 tahun, $60 \%$ pada usia 4 tahun dan $80 \%$ pada usia 6 tahun. 3,5,19,20,27 Keluarga pasien, teman, dan guru harus dijelaskan mengenai keadaan pasien serta harus membaca label setiap makanan siap olah sebelum dikonsumsi. Pada tabel 4 tertera daftar makanan yang mengandung susu sapi.

1. Penghindaran susu sapi pada bayi harus digantikan susu kedele, walaupun demikian 30-40\% kasus ASS akan alergi juga terhadap kedele namun Zeiger $\mathrm{dkk}^{28}$ mendapatkan hanya $14 \%$ ASS yang alergi susu kedele pada anak usia $<3,5$ tahun Eliminasi susu sapi direncanakan selama 6-18 bulan. Bila gejala menghilang, dapat dicoba provokasi setelah eliminasi 6 bulan. Bila gejala tidak timbul lagi berarti anak sudah toleran dan susu sapi dapat diberikan kembali. Bila gejala timbul kembali maka eliminasi dilanjutkan kembali sampai 1 tahun dan seterusnya. Umumnya bayi akan toleran sekitar umur 3 tahun. Bila alergi terhadap susu sapi dan susu kedele dapat diberikan susu sapi hidrolisat.

2. Gejala yang ditimbulkan ASS diobati secara simptomatis

Penghindaran susu sapi juga dilakukan terhadap makanan hasil olahan susu sapi seperti tampak pada Tabel 4.

\section{Pencegahan Alergi Susu Sapi}

Seperti juga tindakan pencegahan alergi secara umum, maka tindakan pencegahn ASS ini dilakukan dalam 3 tahap yaitu, ${ }^{30}$

\section{Pencegahan primer}

Dilakukan sebelum terjadi sensitisasi. Saat

Tabel 4. Label makanan yang mengandung susu sapi

\begin{tabular}{ll}
\hline Artificial butter & Kasein hidrolisat \\
Butter & Susu kambing \\
Buttermilk & Laktalbumin \\
Casein & Laktglobulin \\
Keju & Laktosa \\
Cream & Laktulosa \\
Keju cottage & Sour cream \\
Yoghurt & Whey \\
\hline
\end{tabular}

penghindaran dilakukan sejak pranatal pada janin dari keluarga yang mempunyai bakat atopik. Penghindaran susu sapi berupa pemberian susu sapi hipoalergenik, yaitu susu sapi yang dihidrolisis secara parsial, supaya dapat merangsang timbulnya toleransi susu sapi di kemudian hari karena masih mengandung sedikit partikel susu sapi, misalnya dengan merangsang timbulnya IgG blocking agent. Tindakan pencegahan ini juga dilakukan terhadap makanan hiperalergenik lain serta penghindaran asap rokok.

\section{Pencegahan sekunder}

Dilakukan setelah terjadi sensitisasi tetapi belum timbul manifestasi penyakit alergi. Keadaan sensitisasi diketahui dengan cara pemeriksaan $\operatorname{IgE}$ spesifik dalam serum atau darah talipusat, atau dengan uji kulit. Saat tindakan yang optimal adalah usia 0 sampai 3 tahun. Penghindaran susu sapi dengan cara pemberian susu sapi non alergenik, yaitu susu sapi yang dihidrolisis sempurna, atau pengganti susu sapi misalnya susu kedele supaya tidak terjadi sensitisasi lebih lanjut hingga terjadi manifestasi penyakit alergi. Selain itu juga disertai tindakan lain misalnya imunomodulator, Th1immunoajuvants, probiotik serta penghindaran asap rokok. Tindakan ini bertujuan mengurangi dominasi sel limfosit Th2, diharapkan dapat terjadi dalam waktu 6 bulan.

\section{Pencegahan tersier}

Dilakukan pada anak yang sudah mengalami sensitisasi dan menunjukkan manifestasi penyakit alergi yang masih dini misalnya dermatitis atopik atau rinitis tetapi belum menunjukkan gejala alergi yang lebih berat misalnya asma. Saat tindakan yang optimal adalah pada usia 6 bulan sampai 4 tahun. Penghindaran juga dengan pemberian susu sapi yang dihidrolisis sempurna atau pengganti susu sapi, serta tindakan lain pemberian obat pencegahan misalnya setirizin, imunoterapi, imunomodulator serta penghindaran asap rokok.

\section{Kesimpulan}

Protein susu sapi merupakan protein asing yang pertama kali dikenal oleh bayi, sehingga ASS sering diderita pada bayi usia dini. Alergi susu sapi dapat 
bermanifestasi berbagai macam penyakit alergi. Pencegahan terjadinya ASS harus dilakukan sejak dini, saat sebelum terjadi sensitisasi terhadap protein susu sapi, yaitu sejak intrauterin. Penghindaran harus dilakukan dengan pemberian susu sapi hipoalergenik yaitu susu sapi yang dihidrolisis parsial untuk merangsang timbulnya toleransi susu sapi di kemudian hari. Bila sudah terjadi sensitisasi terhadap protein susu sapi atau sudah terjadi manifestasi penyakit alergi, maka harus diberikan susu sapi yang dihidrolisis sempurna atau pengganti susu sapi misalnya susu kacang kedele. Alergi susu sapi yang sering timbul dapat memudahkan terjadinya alergi makanan lain di kemudian hari bila sudah terjadi kerusakan saluran cerna yang menetap. Oleh karena itu tata laksana ASS yang tepat sangat diperlukan untuk mencegah alergi.

\section{Daftar Pustaka}

1. Sampson HA.Food allergy. Part I:Immunopathogenesis and clinical disorders. J.Allergy Clin Immunol 1999; 103:717-28.

2. Bock SA.Prospective appraisal of complaints of adverse reactions to foods in children during the first 3 years of life. Pediatrics 1987; 79:683-8.

3. Host Halken S. A prospective study of cow milk allergy in Danish infants during the first years of life.Allergy 1990; 45:587-96.

4. Sicherer Sh,Sampson HA.Food hypersensitivity and atopic dermatitis:Pathofysiology, epidemiology, diagnosis and management. J Allergy Clin Immunol 1999; 104:S114-S22.

5. Guillet G, Guillet MH.Natural history of sensitisation in atopic dermatitis. A 3 year follow up in 250 children: food allergy and high risk of respiratory symptoms.Arch Dermatol 1992; 128:187-92.

6. Burks AW, James JM,Hiegel A,Wilson G, dkk. Atopic dermatitis and food hypersensitivity reactions. J Pediatr 1998; 132:132-6.

7. Eigenmann PA, Siecherer SH, Borowski TA, Cohen BA. Prevalence of IgE-mediated food allergy among children with atopic dermatitis. Pediatrics 1998; 101:E8

8. Sampson HA. Food allergy. Part 2: diagnosis and management. J Allergy Clin Immunol 1999; 103:981-9.

9. Bocks SA, Sampson HA, Atkins FM, Zeiger RS, Lehrer $S$, et al.Double blind, placebo-controlled food challenge (DBPCFC) as an office procedure: a manual. J Allergy
Clin Immunol 1988; 82:986-97.

10. Jacobson O, Lindberg T. A prospective study of cow's milk protein intolerance in Swedish infants. Acta Paediatr Scand 1979; 68:853-9.

11. Walker WA. Adverse reactions to food in infancy and childhood, J Pediatr 1992; 121:4-6.

12. Burks AW, Sampson HA. Diagnostic approachs to the patient with suspected food allergies. J Pediatr 1992; 121:4-71.

13. Savilahti E .Cow's milk allergy. Allergy 1981; 36:37-88.

14. Bleumink E, Young E. Identification of the atopic allergen in cow's milk. Int Arch Allergy 1968; 34:521-43.

15. Swaisgood HE. Chemistry of milk protein. Dalam: Fox PF,editor. Developments in dairy chemistry, London, Applied Science Publishers, 1982. h. 1-59.

16. Owen G. Infant protein allergy: its orrigin and management. Disampaikan pada kuliah tamu Ilmu Kesehatan Anak FKUI RSCM, Jakarta, 20 Oktober, 1991.

17. Ishizaka K, Ishizaka T, Hornbrook MM. Physiochemical properties of human reaginic antibody. J Immunol 1966; 97:75-84.

18. Sampson HA. Adverse reactions to foods. Dalam: Middleton E, Reed CE, Elliot EF, Adkinson NF, Yunginger JW, Busse WW, penyunting. Allergy, Principle and Practice. Edisi ke-4.St. Louis: Mosby; 1993. h. $1661-86$

19. Bishop MJ, Hasting. Natural history of cow's milk allergy. Clinical outcome. J Pediatr 1990; 116:862-7.

20. Hosking CS, Heine RG, Hill DJ. The Melbourne milk allergy study-two decades of clinical research. Allergy and Clinical Immunol International 2000;12:198-205

21. Hill DJ, Duke AM, Hosking CS, dkk. Clinical manifestations of cow's milk allergy in childhood:II.The diagnosis value of skin tests and RAST. Clin Allergy 1988; 18:481-90.

22. William LW, Bock SL. Skin testing and food challenges for evaluation of food allergy. Immunology and Allergy Clinics of North Amer 1999; 19:479-93.

23. Isolauri E, Turjanmaa K.Combined skin prick and patch testing enhances identification of food allergy in infants with atopic dermatitis. J Allergy Clin Immunol 1996; 97:9-15.

24. Menardo JL, Bousquet J, Rodiere M, Astruc J.Skin test reactivity in infancy. J Allergy Clin Immunol 1989; 75:646-58

25. Bock SA, Sampson HA, Atkins FM, dkk.Double blind placebo controlled food challenge (DBPCFC) as an affice procedure: A manual. J. Allergy Clin Immunol 1988; 82:986-97. 
26. Rogier Schade P. Cow's milk allergy in infancy and childhood. Immunological and clinical aspects. Didapat dari: http//www.library.uu.nl

27. Bishop MJ, Hasting. Natural history of cow's milk allergy. Clinical outcome. J Pediatr 1990; 116:862-7.

28. Zeiger RS,Sampson HA, Bock SA, Burks JR, dkk. Soy allergy in infants and children with IgE associated cow's allergy. J Pediatr 1999; 134:614-22.
29. Bock SA, Atkins FM. Pattern of food hypersensitivity during sixteen years of double blind, placebo-controlled food challenges. J Pediatr 1990; 117:561-7.

30. Warner JO. Prediction and prevention of asthma. Dalam: Naspitz CK, Szefler SJ, Tinkelman DG, Warner JO, penyunting. Textbook of Pediatric Asthma. An International Perspective. London: Martin Dunitz Ltd, 2001. h. 359-76. 